\title{
Endocrine and metabolic adaptation following caesarean section or vaginal delivery
}

\author{
Jane A Bird, John A D Spencer,Tim Mould, Michael E Symonds
}

\begin{abstract}
The endocrine profile (umbilical venous plasma) of three groups of infants was compared. Samples were taken after eight vaginal deliveries, 11 emergency caesarean sections during labour, and 13 elective caesarean sections before labour. Mean umbilical plasma concentrations of thyroxine and triiodothyronine were significantly higher and cortisol concentration were lower after elective caesarean section compared with the two labour groups. Mean umbilical plasma thyroid stimulating hormone (TSH) concentration was significantly lower after vaginal delivery compared with elective caesarean section.

These results suggest that labour reduces plasma thyroid hormone concentrations at birth in association with a rise in cortisol. These adaptations may be the stimulus for the subsequent surge in triiodothyronine previously reported to occur over the first few hours after birth in vaginally delivered infants.

(Arch Dis Child 1996; 74: F132-F134)
\end{abstract}

Keywords: caesarean section, labour, thyroid hormones.

Infants delivered by caesarean section have lower axillar, intrascapular, and skin temperatures than those delivered per vaginum, ${ }^{1}$ a response which has been linked to a decreased ability to generate heat by brown adipose tissue in lambs. ${ }^{2}$ Studies of infants and lambs have indicated that caesarean section delivery delays or inhibits the postpartum surges in catecholamines and thyroid hormones. ${ }^{23}$ Within 2 hours of birth, however, plasma catecholamine concentrations are very similar in infants delivered vaginally or by caesarean section, ${ }^{4}$ but recent studies have indicated that plasma thyroid hormone concentrations remain lower in caesarean section infants over the first 24 hours of life. ${ }^{5}$

Neonatal plasma concentrations of thyroid hormones are known to peak within 2 hours of birth, ${ }^{6}$ but the influence of labour on both endocrine and metabolic profiles in neonates immediately after birth remains unclear. Our study was designed to examine the influence of labour on the fetal concentration of these factors immediately after birth by comparing umbilical concentrations in groups of babies delivered after labour with a group delivered by caesarean section before labour.

\section{Methods}

CLINICAL METHODS

The babies from 32 uncomplicated pregnancies were studied. Eight labours ended with vaginal delivery and 11 required emergency caesarean section. A further 13 had an elective caesarean section before labour. Umbilical venous blood samples diluted with heparin were obtained immediately after birth from a double clamped segment of umbilical cord. After centrifugation the plasma was collected and stored at $-20^{\circ} \mathrm{C}$ until analysis.

\section{LABORATORY METHODS}

Umbilical plasma concentrations of glucose and non-esterified fatty acids (NEFA) were measured enzymatically, ${ }^{7}$ and triiodothyronine $\left(T_{3}\right)$ and thyroxine $\left(T_{4}\right)$ were measured using radioimmunoassays as described by Clarke et $a l,{ }^{8}$ with the modification that $\mathrm{T}_{3}$ or $\mathrm{T}_{4}$ for calibration curves were prepared in hormone free plasma of human origin (Sigma Chemical Co, Poole, Dorset). Parallelism was observed for these assays using human hormone free plasma.

Umbilical plasma cortisol concentrations were measured using a magnetic solid phase immunoenzymatic assay kit (Cortisol Serozyme, Serono Diagnostics Ltd, Fleet, Hants).

Umbilical plasma TSH concentrations were measured using a two site immunoenzymometric assay kit (NETRIA, St Bartholomew's Hospital, London). Freeze dried hTSH standards were reconstituted in distilled water to yield standard solutions of $38.00,15 \cdot 0,3.80$, $0.95,0.38,0.19$ and $0.00 \mathrm{IU} / \mathrm{ml}$. Aliquots $(50$ $\mu l)$ of each standard or sample were added to 96-well polystyrene microtitre plates which were precoated with ovine polyclonal antihTSH antibody. To each well $200 \mu \mathrm{l}$ of phosphate buffered saline (containing $0.0125 \mathrm{M}$ $\mathrm{Na}_{2} \mathrm{HPO}_{4}, 0.0125 \mathrm{M} \mathrm{NaH} \mathrm{PO}_{4}, 0.25 \mathrm{M} \mathrm{NaCl}$, $\mathrm{pH} 7 \cdot 4$ ) were then added, and then incubated for 18 hours at $21^{\circ} \mathrm{C}$, in the absence of light. Each microtitre well was aspirated and then washed with phosphate buffered saline-Triton $\mathrm{X} 100$ solution (containing $0.0125 \mathrm{M}$ $\mathrm{Na}_{2} \mathrm{HPO}_{4}, 0.0125 \mathrm{M} \mathrm{NaH}_{2} \mathrm{PO}_{4}, 0.15 \mathrm{M} \mathrm{NaCl}$, $0.01 \%(\mathrm{w} / \mathrm{v})$ Triton X100 (AnalaR grade), $\mathrm{pH}$ $7 \cdot 4)$. This process was repeated a further three times, before finally aspirating the wells again. Horseradish peroxidase-conjugated murine monoclonal anti-TSH solution $(250 \mu \mathrm{l})$ (final dilution 1 in 1040 , in $1 \%(w / v)$ bovine serum albumin, $50 \%$ (v/v) glycerol, $0.0125 \mathrm{M}$ $\mathrm{Na}_{2} \mathrm{HPO}_{4}, 0.0125 \mathrm{M} \mathrm{NaH}_{2} \mathrm{PO}_{4}, 0.15 \mathrm{M} \mathrm{NaCl}$, $\mathrm{pH} 7.4$ ) were added to each well and incubated, whilst agitating for 2 hours at $21^{\circ} \mathrm{C}$. The 
Table 1 Limits of detection, inter and intra-assay coefficients of variation (CV)) for hormone assays

\begin{tabular}{lcclc}
\hline Assay & $\begin{array}{l}\text { Upper } \\
\text { limit }\end{array}$ & $\begin{array}{l}\text { Lower } \\
\text { limit }\end{array}$ & $\begin{array}{l}\text { Inter CV } \\
(\%)\end{array}$ & $\begin{array}{l}\text { Intra CV } \\
(\%)\end{array}$ \\
\hline $\mathrm{T}_{4}(\mathrm{nM})$ & 256 & 15 & 2.2 & 3.5 \\
$\mathrm{~T}_{3}$ (nM) & 4.33 & 0.36 & 8.1 & 10.0 \\
TSH (IU/ml) & 28.5 & 3.2 & 3.7 & 2.3 \\
Cortisol (nM) & 1655 & 10 & 5.1 & 1.0 \\
\hline
\end{tabular}

wells were then aspirated. They were then washed and aspirated a further four times, as described above. The horseradish peroxidaseconjugated anti-TSH band in each well was detected by the use of the chromogenic substrate 3,3',5,5'-tetramethylbenzidine (TMB). TMB solution $(200 \mu \mathrm{l})$ (containing $0 \cdot 1 \%(\mathrm{w} / \mathrm{v})$ of TMB in $13 \mathrm{mM} \mathrm{H}_{2} \mathrm{O}_{2}, 0.1 \mathrm{M} \mathrm{C}_{2} \mathrm{H}_{3} \mathrm{O}_{2} \mathrm{Na}$, $0 \cdot 1 \mathrm{M} \mathrm{C}_{6} \mathrm{H}_{5} \mathrm{Na}_{3} \mathrm{O}_{7}, \mathrm{pH} 6 \cdot 2$ ) were added to each well. The microplate was then incubated at $21^{\circ} \mathrm{C}$ for 20 minutes, whilst agitating. A blue colour developed, the absorbance of which was proportional to the amount of horseradish peroxidase present, and hence to the amount of hTSH which was originally incubated with ovine anti-hTSH. The enzymatic reaction was stopped by the addition of $50 \mu \mathrm{l} /$ well of $2 \cdot 5 \mathrm{M}$ $\mathrm{H}_{2} \mathrm{SO}_{4}$ (AnalaR). A yellow colour then appeared with a maximum absorbance at 450nM; the maximum absorbance of each well was read and the concentrations of $\mathrm{TSH}$ in samples were determined from the standard curve.

Limits of detection and intra and interassay coefficients of variation for all hormone assays are given in table 1 .

Means were compared by analysis of variance. A P value of $<0.05$ was considered to represent a significant difference between two means.

Results
Mean gestational age was similar in the two
labour groups, but mean gestation of the elec-
tive caesarean section group was one week
shorter (table 2). The duration of labour was
similar between vaginally delivered and emer-
gency caesarean section groups. There were no
significant differences in birthweight between
groups or in the sex distribution of babies.
Local epidural blockage was administered to
seven mothers in the vaginally delivered group,
nine mothers in the emergency caesarean
section group, and 11 mothers in the elective
caesarean section group. Two mothers in each
caesarean section group also received
halothane general anaesthetic. All babies
established breathing rapidly after birth and
had normal Apgar scores of $8-10$.
Mean umbilical plasma concentration of T
in the two labour groups were significantly

\section{Results} tive caesarean section group was one week shorter (table 2). The duration of labour was similar between vaginally delivered and emergroups or in the sex distribution of babies. Local epidural blockage was administered to seven mothers in the vaginally delivered group, mothers in the emergency caesarean caesarean section group. Two mothers in each caesarean section group also received established breathing rapidly after birth and had normal Apgar scores of 8-10.

Mean umbilical plasma concentration of $\mathrm{T}_{3}$

Table 2 Mean (SEM) birthweight, gestational age, duration of labour and sex of infant lower $(P<0.05)$ than that of the group delivered by elective caesarean section (table 3 ). Mean umbilical plasma $\mathrm{T}_{4}$ concentrations were higher in the elective caesarean section group, although this difference was only significant $(P<0.05)$ when compared with the emergency caesarean section delivered group. Mean umbilical plasma TSH concentrations were also greatest in the elective caesarean section delivered group, but were only significantly $(P<0.01)$ higher than in the labour and vaginal delivery group. In contrast, mean umbilical plasma cortisol concentrations were twice as high $(P<0.05)$ in the labour group compared with the group delivered by elective caesarean section. No significant differences in plasma glucose or NEFA concentrations were observed.

\section{Discussion}

This study indicates the important influence of the labour process on the hypothalamicpituitary-thyroid axis at birth. Plasma thyroid hormone concentrations were clearly lower in babies that had endured the labour process than those in the emergency caesarean section group which also had significantly higher mean plasma TSH concentrations. These findings suggest that the labour process may act to initiate the post partum surges in TSH and thyroid hormones observed 0.5 to 1 hour after birth, ${ }^{2}$ by initially causing a decline in the plasma concentrations of these hormones, although this has yet to be fully established. The exact mechanism by which labour can influence hypothalamic-pituitary-thyroid function has not been determined, but could be related to the physical stress imposed on the fetus during labour: this would stimulate cortisol secretion. No differences in plasma concentration of glucose and NEFA were observed between groups immediately after birth, indicating that these do not have a primary role in altering thyroid hormone secretion after birth.

The observation of higher plasma $T_{3}$ concentrations, but lower cortisol concentrations, in infants delivered by elective caesarean section, indicates that in contrast to the ovine species, ${ }^{9}$ labour is an important signal in mediating changes in thyroid hormone metabolism in term infants. The higher plasma cortisol concentrations in babies who had endured the labour process compared with those in the emergency caesarean section group can be explained in part by differences in gestational age, as cortisol concentrations are known to increase rapidly over the final days of gestation. ${ }^{10}$ In sheep, however, cortisol increases plasma $T_{3}$ concentrations, ${ }^{11}$ which does not seem to be the case in the present study. Furthermore, the occurrence of high plasma concentrations of cortisol with low TSH concentrations agrees with the finding that prenatal dexamethanone treatment significantly reduces TSH secretion after birth, ${ }^{12}$ although in this study no measurements of $\mathrm{T}_{4}$ and $\mathrm{T}_{3}$ were made. It is also known that human placenta catalyses the inner ring 5-monodeiodination of $T_{4}$ and $T_{3}$ to their 
Table 3 Mean (SEM) plasma concentrations of $T_{3}, T_{4}, T S H$, cortisol, glucose and NEFA

\begin{tabular}{|c|c|c|c|c|c|c|}
\hline & $\begin{array}{l}T_{3} \\
(n M)\end{array}$ & $\begin{array}{l}T_{4} \\
(n M)\end{array}$ & $\begin{array}{l}\text { TSH } \\
(I U / m l)\end{array}$ & $\begin{array}{l}\text { Cortisol } \\
(n M)\end{array}$ & $\begin{array}{l}\text { Glucose } \\
\text { (mM) }\end{array}$ & $\begin{array}{l}N E F A \\
(m M)\end{array}$ \\
\hline $\begin{array}{l}\text { Vaginal delivery }(n=8) \\
\text { Emergency caesarean section }(n=11) \\
\text { Elective caesarean section }(n=13)\end{array}$ & $\begin{array}{l}0.68(0.05)^{\mathrm{c}} \\
0.79(0.04)^{\mathrm{b}} \\
1.11(0.11)^{\mathrm{a}}\end{array}$ & $\begin{array}{c}92(7) \\
85(4)^{\mathrm{b}} \\
109(8)^{\mathrm{a}}\end{array}$ & $\begin{array}{l}4 \cdot 9(0 \cdot 7)^{\mathrm{c}} \\
6 \cdot 5(1 \cdot 4) \\
7 \cdot 8(0 \cdot 5)^{\mathrm{a}}\end{array}$ & $\begin{array}{l}512(105)^{\mathrm{b}} \\
525(121)^{\mathrm{b}} \\
271(21)^{\mathrm{a}}\end{array}$ & $\begin{array}{l}3 \cdot 7(0 \cdot 6) \\
3 \cdot 1(0 \cdot 3) \\
2 \cdot 5(0 \cdot 4)\end{array}$ & $\begin{array}{l}0.72(0 \cdot 10) \\
0 \cdot 71(0 \cdot 06) \\
0 \cdot 61(0.05)\end{array}$ \\
\hline
\end{tabular}

${ }^{a b} \mathrm{P}<0.05 ;{ }^{a c} \mathrm{P}<0.01$

inactive metabolites. ${ }^{13}$ A potential explanation for lower plasma thyroid hormone concentrations in babies who had endured labour is that placental monodeiodination was enhanced in response to alterations in placental blood flow during labour.

In conclusion, the present study indicates that the labour process resulted in a reduction in circulating plasma thyroid hormones at birth. A study of newborn infants to see if these differences have clinical consequences is therefore warranted.

We thank Dr R Edwards and his staff at St Bartholomew's Hospital, for their kind assistance with the measurement of TSH in our plasma samples.

This work was funded by The Wellcome Trust, and Jane A Bird was supported by a Biotechnology and Biological Sciences Research Council Studentship.

1 Christensson K, Siles C, Cabrera T, Belaustequi A, De La Fuente P, Lagercrantz $H$, Puyol P, Winberg J. Lower body temperatures in infants delivered by caesarean section than vaginally delivered infants. Acta Paediatr Scand 1993; 82: 128-31.

2 Symonds ME, Clarke L, Lomax MA. The regulation of neonatal metabolism and growth. In: Ward RH, Smith SK, Donnai D, eds. Early fetal growth and development. London: Royal College of Obstetricians and Gynaecologists, 1994: 407-19.

3 Irestedt L, Lagercrantz H, Hjemdahl P, Hagnevik K, Belfrage P. Fetal and maternal plasma catecholamine Belfrage P. Fetal and maternal plasma catecholamine
levels at elective cesarean section under general or levels at elective cesarean section under general or
epidural anesthesia versus vaginal delivery. Am $\mathcal{f}$ Obstet epidural anesthesia versus va
Gynecol 1982; 142: 1004-10.
4 Hagnevik K, Faxelius G, Irestedt L, Lagercrantz H, Lundel $B$, Persson B. Catecholamine surge and metabolic adaptation in the newborn after vaginal delivery and caesarean section. Acta Paediatr Scand 1984; 73: 602-9.

5 Bagnoli F, Manno C, Tomasini B, Zanai S, Buonocore G, Pecciarini L, Dehev V. Neonatal thyroid hormones in relation to mode of delivery. In: Cosmo EV, Di Renzo GC, eds. Proceedings of the Second World Congress of Perinatal Medicine, 1993: 391.

6 Simila S, Koivisto M, Ranta T, Leppaluto J, Reinila M, Haapalahti J. Serum tri-iodothyronine, thyroxine and thyrotrophin concentrations in newborn during the first 2 days of life. Arch Dis Child 1975; 50: 565-76.

7 Symonds ME, Bryant MJ, Lomax MA. The effect of shearing on the energy metabolism of the pregnant ewe. Br ₹ Nutr 1986; 56: 635-43.

8 Clarke L, Darby CJ, Lomax MA, Symonds ME. Effect of ambient temperature during the 1st day of life on thermoregulation in lambs delivered by cesarean section f Appl Physiol 1994; 76: 1481-8.

9 Thomas AL, Krane EJ, Nathanielsz PW. Changes in the fetal thyroid axis after induction of premature parturition by low dose continuous intravascular cortisol infusion to the fetal sheep at 130 days of gestation. Endocrinol 1978; the fetal she

10 Silver M. Prenatal maturation, the timing of birth and how it may be regulated in domestic animals. Exp Physiol 1990; 75: $285-307$.

11 Fraser M, Liggins GC. The effect of cortisol on thyroid hormone kinetics in the ovine fetus. $\mathcal{f}$ Dev Physiol 1989 11: 207-11.

12 De Zegher F, Vanhole C, Van Den Berghe G, Devlieger H, Eggermont E, Veldhuis JD. Properties of thyroid-stimulating hormone and cortisol secretion by the human newborn on the day of birth. $\mathcal{F}$ Clin Endocrinol Metab 1994; 79: 576-81.

13 Roti E, Fang SL, Green K, Emerson CH, Braverman LE. Human placenta is an active site of thyroxine and $3,3^{\prime}$ 5-triiodothyronine tyrosol ring deiodination. $f$ Clin Endocrinol Metab 1981; 53: 498-501. 